УДК 159.922.6: 159.942: 159.925

DOI https://doi.org/10.26661/2310-4368/2021-1-6

\title{
ОСОБЛИВОСТІ ЕМОЦІЙНОГО ІНТЕЛЕКТУ ТА КОПІНГ-СТРАТЕГІЙ У СТРУКТУРІ ПРОФЕСІЙНОГО РОЗВИТКУ МОЛОДИХ І ДОСВІДЧЕНИХ ФАХІВЦІВ СУЧАСНИХ СОЦІОНОМІЧНИХ ПРОФЕСІЙ
}

\author{
Коллі-Шамне А. В. \\ доктор психологічних наук, професор, \\ професор кафедри психології і педагогіки дошкільної освіти \\ Університет Григорія Сковороди в Переяславі \\ вул. Сухомлинського, 30, Переяслав, Київська область, Україна \\ orcid.org/0000-0003-1541-6079 \\ shamne@ukr.net \\ Руденко Д. В. \\ аспірант кафедри психологіі \\ Університет Григорія Сковороди в Переяславі \\ вул. Сухомлинського, 30, Переяслав, Київська область, Україна \\ orcid.org/0000-0001-5581-2776 \\ rudymon96@gmail.com
}

\begin{abstract}
Ключові слова: професійний розвиток, молоді (досвідчені) фахівиі, емоиійний інтелект, копінг-стратегії, особистість професіонала, задоволеність працею.
\end{abstract}

У статті розглядається динаміка особистісних якостей та поведінкових стратегій представників сучасних соціономічних професій (маркетологи, аккаут-менеджери, спеціалісти 3 контент-маркетингу) на різних етапах їхнього професійного розвитку. Розглянуто проблематику професійного розвитку як складної взаємодії особистісного, професійного та фахового розвитку людини. Проаналізовано поняття емоційного інтелекту та його значення для успішної професійної діяльності фахівців. Проаналізовано також деякі якості особистості, які пов'язані з ефективністю професійної діяльності (емоційний інтелект, копінг-стратегії, задоволеність професійною діяльністю, об'єктивне та суб'єктивне благополуччя тощо).

В емпіричному дослідженні використовувалися «Опитувальник компонентів задоволення працею» (Іванова Т.Ю., Рассказова Є.І., Осин С.М.), опитувальник емоційного інтелекту «ЕмІн» (Д.В. Люсін), методика «Копінг - поведінка в стресових ситуаціях» (Норман С. Ендлер та з Джеймс А. Паркер, адаптований варіант Т.Л. Крюкової). Вибірка складалася з 48 працівників відділу контенту та маркетингу і акаунт-відділу компанії КТ Україна (Dnipro-M, м. Київ) від 22 до 35 років, які є представниками сучасних соціономічних професій. Розглянуто відмінності показників емоційного інтелекту та копіг-стратегій у структурі професійного розвитку молодих (стаж роботи від 1 до 3 років) та досвідчених (стаж роботи - від 5 до 10 років) працівників цих відділів. Відмінності між ними розглянуто як із погляду рівня розвитку цих показників, так і з погляду структурних зв'язків між їхніми компонентами. Емоційний інтелект та копінг-стратегії проаналізовано як сукупність здатностей, які виступають психологічним ресурсом і одночасно результуючим ефектом професійного розвитку. Визначено, що розвиток особистості професіонала $\epsilon$ системним процесом, який пов'язаний із набуттям професійного досвіду та задоволенням працею. Означено перспективи вивчення задоволення працею та суб'єктивного благополуччя як предикторів успішного професійного розвитку фахівців соціономічних професій. 


\title{
FEATURES OF EMOTIONAL INTELLIGENCE AND COPING-STRATEGIES IN THE STRUCTURE OF PROFESSIONAL DEVELOPMENT OF YOUNG AND EXPERIENCED SPECIALISTS OF MODERN SOCIONOMIC PROFESSIONS
}

\author{
Kolly-Shamne A. V. \\ Doctor of Psychological Sciences, Professor, \\ Professor at the Department of Psychology and Pedagogy of Preschool Education \\ Hryhoriy Skovoroda University in Pereyaslav \\ Sukhomlynskyi str., 30, Pereiaslav, Kyiv region, Ukraine \\ orcid.org/0000-0003-1541-6079 \\ shamne@ukr.net \\ Rudenko D. V. \\ Postgraduate Student at the Department of Psychology \\ Hryhoriy Skovoroda University in Pereyaslav \\ Sukhomlynskyi str., 30, Pereiaslav, Kyiv region, Ukraine \\ orcid.org/0000-0001-5581-2776 \\ rudymon96@gmail.com
}

Key words: professional development, young (experienced) specialists, emotional intelligence, coping strategies, professional personality, job satisfaction.
The article describes the dynamics of personal qualities and behavioral strategies of modern socionomic professions (marketers, account managers, content marketers) at different stages of their professional development. Also our research considers professional development as a complex interaction of personal, professional and speciality development. The concept of emotional intelligence and its significance for successful professional activity of specialists is analyzed. Some personality traits that are related to the effectiveness of professional activities (emotional intelligence, coping strategies, job satisfaction, objective and subjective well-being, etc.) are reviewed as well.

The empirical study used the "Questionnaire of components of job satisfaction" (Ivanova T.Yu., Rasskazova E.I., Osin E.M.), the questionnaire of emotional intelligence "EmIn" (D.V. Lusin), the method of "Copingbehavior in stressful situations" (Norman S. Endler and James A. Parker, adapted version of T.L. Kryukova). The sample consisted of 48 employees of the content and marketing department and the account department of CT Ukraine (Dnipro-M, Kyiv) from 22 to 35 years old, who are representatives of modern socionomic professions. The differences between the indicators of emotional intelligence and coping-strategies in the structure of professional development of young (work experience from 1 to 3 years) and experienced (work experience - from 5 to 10 years) employees of these departments are considered. The differences between them are examined in terms of both - the level of development of these indicators, and in terms of structural relationships between their components as well. Emotional intelligence and coping-strategies are analyzed as a set of abilities that act as a psychological resource and at the same time the resulting effect of professional development. It is determined that the development of a professional's personality is a systemic process that is associated with gaining professional experience and job satisfaction. Prospects of studying job satisfaction and subjective wellbeing were identified as predictors for successful professional development of socionomic professions. 
Постановка проблеми. Сучасні соціально-економічні та суспільні трансформації викликають об'єктивні процеси зростання ролі професіоналізму у всіх сферах діяльності людини, появу нових вимог до особистості та умов професійного розвитку сучасного фахівця. Сучасний ринок праці потребує спеціалістів, які володіють не тільки відповідною кваліфікацією, але певними мотиваційними, когнітивними, емоційно-вольовими характеристиками (стресостійкість, емоційний інтелект, самоконтроль, здатність до адаптації, ефективні копінг-стратегії тощо), які дозволяють домагатися не тільки об'єктивного чи суб'єктивного кар'єрного успіху, але й життєвого успіху в цілому. Ці якості виявляються особливо значущими, якщо мова йде про фахівців сучасних соціономічних професій, які передбачають безпосереднє спілкування як з людьми, так і з великими обсягами інформації.

Якщо на перших етапах професійного розвитку формування цих якостей постає одним 3 завдань вищого навчального закладу, то на подальших етапах кар'єри вони є результатом набутого життєвого та професійного досвіду і саморозвитку сучасних фахівців. Тому постає проблема розвитку тих особистісних якостей фахівців, які забезпечують, з одного боку, об'єктивну та суб'єктивну успішність професійної діяльності, з іншого, задоволення нею, достатній рівень суб'єктивного благополуччя фахівців. Це особливо актуально для представників відносно нових соціономічних професій (маркетологи, акаут-менеджери, менеджери по роботі 3 клієнтами, спеціалісти з контент-маркетингу).

Специфіка цих професій зумовлена стресогенним характером їхньої професійної діяльності, невід'ємними складовими якої є високий ступінь відповідальності, вміння працювати у швидко змінюваних умовах, багатозадачність професійної діяльності, інтенсивність соціальних контактів, високий рівень організаторських здібностей та здатність працювати у команді, постійний запит на креативність, здатність генерувати ідеї та знаходити нестандартні рішення, вміння працювати 3 запереченнями та вести переговори, часто ненормований робочий графік і пов'язане 3 ним можливе професійне вигорання від великого обсягу інформації та постійного спілкування з великою кількістю дуже різних людей. Тому уваги потребують ті їх особистісні зміни, які відбуваються в процесі опанування і здійснення цієї професійної діяльності, і відповідно зумовлюються характером цієї діяльності. Тому предметом дослідження виступили особистісні характеристики фахівців сучасних соціономічних професій як результуючий ефект та психологічний ресурс їх успішного професійного розвитку.
Мета дослідження полягала у вивченні особистісних характеристик (на прикладі емоційного інтелекту) та поведінкових стратегій (на прикладі копінг-стратегій) представників сучасних соціономічних професій (маркетологи, акаунт-менеджери, спеціалісти 3 контент-маркетингу) на різних етапах професійного розвитку. Завдання дослідження полягали у наступному: проаналізувати проблематику особистісних чинників професіогенезу, визначити особливості задоволеності працею, емоційного інтелекту та копінг-стратегій фахівців в контексті набуття ними професійного досвіду, здійснити порівняльний аналіз емоційного інтелекту та копінг-стратегій молодих та досвідчених фахівців соціономічних професій в сучасній організації.

Виклад основного матеріалу дослідження. Професійний розвиток людини $\epsilon$ складним, суперечливим i багатогранним процесом, який складається 3 особистісного, професійного та фахового розвитку [15; 29 та ін.]. Міждисциплінарність та складність цього феномену зумовлює появу великої кількості дефініцій та багатьох спроб категоріального аналізу цього поняття $[3 ; 6 ; 12 ; 25$ та ін.]. Навіть для позначення професійного розвитку у вітчизняних і зарубіжних наукових працях використовуються різні терміни, наприклад, професіогенез, професійний розвиток (professional development), розвиток кар'єри (career development), розвиток персоналу (staff development), розвиток людських ресурсів (human resource development) i, відповідно, різні підходи.

Оскільки це поняття становить центр наших наукових пошуків, визначимо, що професійний розвиток ми розуміємо як процес соціалізації, спрямований на привласнення людиною різноманітних аспектів світу праці - професійних ролей, професійної мотивації, професійних знань, умінь та навичок. Професійний розвиток особистості пов'язаний з розвитком особистості взагалі, iз засвоєнням нового досвіду, знань, вмінь та із трансформацією мотивації й інтересів конкретної людини [28]. Іншими словами, професійний розвиток означає становлення та подальшу інтеграцію у професійній праці особистісних якостей і здібностей, професійних знань та умінь. Саме тому в сучасній науковій літературі дедалі частіше йдеться про поняття професіогенез фахівця, зміст якого є предметом багатьох теоретико-методологічних пошуків та спроб систематизації змісту цієї категорії [3; 5; 6; 10; 15; 25 та ін.]. У сучасній психології професіогенез розглядається як цілісний, безперервний процес становлення фахівця i професіонала, який триває з моменту вибору професії і завершується, коли людина припиняє професійну діяльність $[15$, с.8]. 
Як і більшість психологів, категорію професіогенезу та перелік описаних ним явищ ми розглядаємо у межах персоналістичного рівня. Під професіогенезом ми розуміємо розвиток людини, під час якого відбуваються зміни і перетворення структури ii особистісних якостей, зумовлені засвоєнням і здійсненням професійної діяльності [6, с. 60]. Йдеться про формування не окремих якостей, а особистості в цілому. Є.Ф. Зєєр використовує термін «професійне становлення особистості» (на відміну від професійного становлення суб'єкта діяльності), який є процесом прогресивної зміни особистості під дією професійної діяльності і власної активності, спрямованої на самовдосконалення і самоздійснення [12].

Поняття професіогенезу відображує закономірності соціального і психологічного розвитку суб' єкта діяльності на етапах професійного шляху та передбачає можливість активного управління процесом професіоналізації [3]. Для нас є суттєвим $\epsilon$ те, що підхід, заснований на цьому понятті, має орієнтуватися на вивчення особливостей розвитку особистості професіонала, на аналіз психологічних механізмів регуляції професійної діяльності, взаємоузгодження ресурсних можливостей людини і професійних вимог. Таким чином, поняття професіогенез стає дотичним до поняття особистісний професіогенез. На думку багатьох дослідників, він відбувається за двома напрямами, які співвідносяться з формуванням внутрішньої і зовнішньої професійної ідентичності [10,3 та ін.]. Предмет наших пошуків центрується на першому 3 них - на розвитку професійно зумовлених підструктур особистості.

У контексті цих теоретичних позицій для нас інтерес становили ті внутрішні ресурси і здатності, які, з одного боку, забезпечують реалізацію особистісних ресурсів та можливостей у професійній діяльності, з іншого, зворотний вплив професіогенезу на їх становлення. До особистісних структур, які $є$ внутрішніми індивідуальними ресурсами фахівців досліджуваних професій, ми відносимо емоційний інтелект (ЕI), копінг-стратегії, об'єктивне та суб'єктивне благополуччя, задоволеність працею, професійну мотивацію, саморегуляцію поведінки. У даній роботі увага зосереджена на перших двох 3 цих особистісних структур (емоційний інтелект та копінг-стратегіï), серед яких основну увагу ми приділяли динаміці емоційного інтелекту, який є важливою умовою професійного розвитку [4; 20 та ін.].

Термін «емоційний інтелект» (ЕI) був популяризований Д. Гоулменом [7], який значною мірою ототожнював емоційний інтелект 3 «правильною» соціальною поведінкою. Введення цього поняття в психологічний тезаурус активізувало декілька споріднених напрямів його дослі- дження: операціоналізація ЕI як емоційно-інтелектуального конструкту, вивчення зв'язку між складовими ЕІ та лідерськими, управлінськими якостями, розвиток ЕІ та його складових, дослідження адаптаційного потенціалу емоційного інтелекту в особистому та професійному розвитку тощо $[1 ; 19 ; 23 ; 24$ та ін.].

Теоретичною основою нашого дослідження були теорії емоційного інтелекту Д. Гоулман (теорія емоційної компетентності, ЕІ як мішана модель, що об'єднує когнітивні здібності і особистісні якості), Р. Бар-Он (некогнітивна теорія емоційного інтелекту, ЕІ як мішана модель, що об'єднує некогнітивні здібності і є особистісною характеристикою), Х. Вайсбах і У. Дакс (емоційний інтелект як уміння «інтелектуально» керувати своїм емоційним життям), Дж. Майєр, П. Селовей, Д. Карузо (теорія емоційно-інтелектуальних здібностей, ЕІ як модель когнітивних здібностей), Д. Люсін (двокомпонентна теорія ЕI).

Нині все різноманіття теорій і концепцій емоційного інтелекту зводиться до двох основних: до змішаних моделей і моделі здібностей (модель Дж. Маєра, П. Саловея і Д. Карузо). Дана досить умовна класифікація має під собою широкий пласт наукових дискусій [36; 37]. Змішані моделі були представлені, наприклад, такими дослідниками як Р. Бар-Он, який трактує емоційний інтелект як «безліч некогнітивних здібностей і навичок, які впливають на здатність успішно справлятися 3 вимогами і тиском оточення» [32, с. 378].

Д. Маєр і П. Саловей зробили акцент на когнітивній складовій емоційного інтелекту, пов'язаній 3 переробкою інформації про емоції. Поняття емоційного інтелекту отримало нове визначення - як здатність переробляти інформацію, що міститься в емоціях: визначати значення емоцій, їх зв'язки один 3 одним, використовувати емоційну інформацію в якості основи для мислення і прийняття рішень [37]. К. Петрідес і Е. Фьорнхем визначили емоційний інтелект в межах теорії рис як сукупність поведінкових схильностей і здатності розпізнавати, обробляти і використовувати емоційну інформацію. Цей конструкт включає в себе емпатію, імпульсивність і наполегливість, а також елементи соціального інтелекту [38].

Д.В. Люсін визначає емоційний інтелект як психологічний конструкт, який формується в ході життя людини під впливом ряду факторів (когнітивні здібності, емоції, індивідуальні прояви емоційності). Емоційний інтелект, на думку Д.В. Люсіна, можна уявити як конструкт, який має подвійну природу і пов'язаний, з одного боку, 3 когнітивними здібностями, а 3 іншого боку - 3 особистісними характеристиками [18]. Розроблена Д.В. Люсіним методика визначення рівня емоційного інтелекту «Емінем», яку ми викори- 
стали в емпіричному дослідженні, має досить високу надійність і валідність [18].

Отже, серед особистісних властивостей, які пов'язані $з$ професійним розвитком представників соціономічних професіях, феномен емоційного інтелекту нас цікавив в першу чергу, тому що він $\epsilon$ інтеграцією емоційних і когнітивних аспектів соціального пізнання, чинником психосоціальної адаптації, особистісного та професійного розвитку людини. Тому другий аспект теоретичного аналізу полягав у вивченні ролі емоційного інтелекту як психологічного ресурсу професійного розвитку особистості, його взаємозв'язку з ефективністю професійної діяльності та впливу на успішність виконання певної професійної діяльності. Особливу увагу ми звернули на роботи, в яких виявлено зв'язки між показниками емоційного інтелекту та особливостями професійної діяльності, значна кількість 3 яких присвячена зв'язку показників емоційного інтелекту 3 лідерськими та управлінськими якостями, а також з'ясуванню ролі емоційного інтелекту у професійній підготовці та у професійній діяльності $[2 ; 4 ; 8 ; 14 ; 16$; $20 ; 21 ; 22 ; 24$ та ін.]. Взаємозв’язок рівня розвитку емоційного інтелекту керівників і ефективності їх діяльності доведено у багатьох $з$ цих досліджень.

Високий рівень ЕI корелює із здатністю до ефективної управлінської діяльності $[2 ; 21 ; 22 ; 39$ та ін.]. Менеджери з високим ЕI здатні культивувати продуктивні робочі взаємини із співробітниками та клієнтами, мають більш високу особисту продуктивність. Високий рівень розвитку ЕI керівників також сприяє вибору стратегії і поведінки, яке сприяє досягненню цілей організації. Петровська А. довела, що керівники із середнім і високим рівнем емоційного інтелекту менш схильні вибирати маніпулятивні, асоціальні і агресивні дії в якості моделей розв'язання робочих ситуацій, менш схильні використовувати деструктивні, асоціальні стратегіï [22]. За результатами західних досліджень керівники 3 високим рівнем емоційного інтелекту використовують більш ефективний трансформаційний стиль керівництва, а 3 низьким - транзакційний стиль. Власне емоційний інтелект пов'язаний з усіма видами трансформаційного лідерства [41]. Саме ЕI забезпечує лідера гнучким стилем поведінки, високою здатністю впливати на інших, бути уважним до себе і інших, стимулювати тощо. Було визначено взаємозв'язок між емоційним інтелектом і лідерською поведінкою як передумову до успішної діяльності групи, виявлена залежність між емоційним інтелектом і гнучким стилем лідерства та зворотна залежність між емоційним інтелектом і пасивно - уникаючим стилем керівництва $[31 ; 33 ; 35 ; 39 ; 40 ; 41]$.

У межах проблеми залученості і суб'єктивної задоволеності людини в професійній сфері вста- новлено кореляційні взаємозв'язки між рівнем емоційного інтелекту лідера (менеджера) і рівнем залученості членів робочих груп у роботу компанії, виявлена кореляція між продуктивністю фахівців і здатністю сприймати і використовувати емоції [39].

У численних дослідженнях доведено, що фахівці з високим рівнем розвитку ЕI мають тенденцію бути більш соціально-відповідальними, мають більш якісні міжособистісні стосунки та взаємовідносини, більш сприйнятливі до емоцій інших людей. Високий рівень емоційного інтелекту $\epsilon$ предиктором високих професійних та соціальні результатів, натомість низький рівень емоційного інтелекту у людини 3 більшою ймовірністю прогнозує міжособистісні конфлікти і ситуації дезадаптації $[2 ; 14 ; 22 ; 30 ; 33)$.

Тісно пов'язані емоційний інтелект, стиль лідерства i механізми вирішення проблем працівниками. Результати досліджень доводять, що лідери і підлеглі з розвиненим емоційним інтелектом краще аналізують і вирішують проблемні ситуації. Знижений рівень ЕI підвищує ймовірність неефективного подолання труднощів та використання неефективних стратегій вирішення проблем, що веде до підвищення рівня стресу [42].

Доведено взаємозв'язок між емоційним інтелектом, копінг-стратегіями і суб'єктивним благополуччям в ситуації стресу на робочому місці. Індивідуальні відмінності в розумінні емоційних процесів відіграють помітну роль у виборі способу подолання особистісного i професійного стресу для досягнення суб'єктивного благополуччя; емоційний інтелект підсилює адаптивне подолання труднощів, пов'язаних 3 міжособистісними конфліктами і професійним стресом [9; 24; 19; 20; 27 та ін.]. Виявлено зв'язки між емоційним інтелектом і психологічними властивостями, що забезпечують долаючу (копінг) поведінку і соціальну адаптацію особистості [11].

Виходячи 3 теоретичного аналізу, у розвитку емоційного інтелекту фахівців сучасної організації нас передусім цікавила професійно зумовлена динаміка їх здатності до розуміння й управління емоціями, яку ми розглядали як внутрішній ресурс успішної копінг-поведінки особистості та в більш широкому сенсі - як фактор успішності людини в особистісній та професійній сфері. Одним 3 прикладів зазначеної «ресурсності» $€$ процес подолання складних, проблемних ситуацій професійного розвитку. Тому, з точки зору емпіричних завдань дослідження, проблематику EI у професійному розвитку ми розглядали в контексті регуляції поведінки фахівцями у стресових ситуаціях, які вимагають напруження людських ресурсів і включення особливих механізмів для їх подолання - копінг-поведінки. 
Методи та вибірка дослідження. В емпіричному дослідженні взяли участь працівники відділу контенту та маркетингу і акаунт-відділу центрального офісу компанії КТ Україна (Dnipro-M, м. Київ) у кількості 48 осіб віком від 22 до 35 років (маркетологи, акаунт-менеджери, спеціалісти 3 контент-маркетингу).

3 метою визначення ролі зазначених показників у професійному розвитку вибірка була поділена на 2 вікові групи: 1) група молодих працівників зі стажем роботи від 1 до 3 років (22-28 років); 2) група досвідчених працівників зі стажем роботи від 5 до 10 років (33-37 років).

Маркетологи, акаунт-менеджери, спеціалісти 3 контент-маркетингу є представниками сучасних соціономічних (тип «людина-людина») професій. У сучасній психологічній науці підкреслюється емоціогенний характер цих професій, пов'язаний $з$ високим ступенем відповідальності, інтенсивними міжособистісними відносинами, високими вимогами до ефективної емоційно-вольової регуляції. Представники професій цього типу сенситивні до емоційного вигорання та впливу стресових факторів, пов'язаних з високим рівнем невизначеності. Тому на першому етапі емпіричного дослідження ми намагалися «елімінувати» чинник низького задоволення працею та закономірно пов'язаної з ним (див., напр., [26]) демотивації та емоційного вигорання персоналу. Для цього ми визначили рівень задоволення працею та професійної мотивації учасників дослідження («Опитувальник компонентів задоволення працею» [13], який включає діагностику трьох груп компонентів задоволеності працею (соціальних, внутрішньо організаційних і особистісних компонентів) та містить 5 шкал: «Задоволеність заробітною платою», «Задоволеність умовами і організацією праці», «Задоволеність керівництвом», «Задоволеність колективом», «Задоволеність процесом і змістом праці». За результатами цього тесту з загальної вибірки були виключено 8 учасників (16,7 \%) низьким рівнем задоволення працею (за більшістю шкал опитувальника). Таким чином, остаточна вибірка складалася з 42 осіб.

Для емпіричної оцінки рівня ЕI використовувався опитувальник емоційного інтелекту «ЕмІн» (Д. Люсін), який вимірює ЕІ як здатність до розуміння власних емоцій та управління ними [18]. Для емпіричної оцінки копінг-стратегій використовувалася методика «Копінг - поведінка в стресових ситуаціях» (Норман С. Ендлер та з Джеймс А. Паркер, адаптований варіант Т.Л. Крюкової).

Аналіз отриманих результатів. Порівняльний аналіз результатів діагностики молодих та досвідчених фахівців показав, що у досвідчених фахівців окремі показники емоційного інтелекту достовірно вищі. Значний відсоток молодих пра- цівників мають низький та дуже низький рівні EI за шкалами «Розуміння емоцій власних та інших людей» $(45 \%)$, «Розуміння власних емоцій» $(20 \%)$, «Внутрішньо особистісний емоційний інтелект» (20 \%), «Контроль експресії» (20\%) та «Управління власними емоціями» (32 \%). Водночас, тільки 3-7 \% 3 них показали високий рівень ЕI за окремими шкалами ЕI. Інакше кажучи, значна частина молодих фахівців має проблеми з розумінням та розрізненням емоцій як власних, так i оточуючих людей, недостатньо усвідомлює причини їх виникнення, має низький рівень здатності управління власними емоціями та контролю зовнішніх проявів власних емоцій. Натомість серед досвідчених фахівців переважають середні (у 60-72\% за різними шкалами EI) та високі (12-27 \%) показники ЕI. Найбільші відмінності між досліджуваними групами спостерігаються за шкалою «Розуміння власних емоцій». Серед молодих фахівців низький та дуже низький рівні цього показника виявлено у $45 \%$, серед досвідчених працівників тільки $8 \%$. Порівняння середніх за критерієм Стьюдента для незалежних вибірок показало, що середні бали за цим показником (відповідно 3,82 і 14,57) значуще відрізняються на рівні $\mathrm{p} \leq 0,01$ (Табл. 1 ).

За шкалами «Управління власними емоціями», «Внутрішньо особистісний емоційний інтелект», «Міжособистісний емоційний інтелект» та «Розуміння емоцій власних та інших людей» у досвідчених фахівців показники також вище в середньому на 15-25\%. Відмінності середніх балів цих показників достовірні на рівні $\mathrm{p} \leq 0,05$. Відсутні значущі відмінності за шкалами «Управління власними та чужими емоціями», «Управління емоціями інших», «Контроль експресії» та за загальним показником «Загальний емоційний інтелект».

Отже, досвідчені фахівці виявляють більш високу здатність бачити, вирізняти та приймати власні позитивні і негативні емоції, емоційні слабкості та недоліки, розуміти їх та контролювати, створюючи таким чином умови для задоволення особистих потреб i досягнення професійних цілей. Професійний розвиток конкретизується у розвитку уміння розпізнавати, ідентифікувати власні емоцій.

Отже, досвідчені фахівці виявляють більш високу здатність бачити, вирізняти та приймати власні позитивні і негативні емоції, емоційні слабкості та недоліки, розуміти їх та контролювати, створюючи таким чином умови для задоволення особистих потреб i досягнення професійних цілей. Професійний розвиток конкретизується у розвитку уміння розпізнавати, ідентифікувати власні емоцій.

Емпіричне дослідження специфіки копінг-поведінки молодих та досвідчених працівників 
Таблиця 1

Середні значення компонентів емоційного інтелекту фахівців компанії за методикою «Опитувальник емоційного інтелекту «ЕмІн» (Д.В. Люсін) $\mathrm{N}=42$

\begin{tabular}{|l|c|c|}
\hline \multicolumn{1}{|c|}{ Шкала } & \multicolumn{2}{c|}{ Середні значення } \\
\cline { 2 - 3 } & $\begin{array}{c}\text { Молоді фахівці } \\
\mathbf{( N = 2 1 )}\end{array}$ & $\begin{array}{c}\text { Досвідчені фахівці } \\
\mathbf{( N = 2 1 )}\end{array}$ \\
\hline Розуміння емоцій інших & 9,05 & 13,57 \\
\hline Управління емоціями інших & 5,64 & 7,73 \\
\hline Розуміння власних емоцій & $3,82^{* *}$ & $13,68^{* *}$ \\
\hline Управління власними емоціями & $4,15^{*}$ & $7,45^{*}$ \\
\hline Контроль експресії & 3,97 & $17,83^{*}$ \\
\hline Міжособистісний емоційний інтелект & $7,28^{*}$ & $11,34^{*}$ \\
\hline Внутрішньо особистісний емоційний інтелект & $4,27^{*}$ & $10,68^{*}$ \\
\hline Розуміння емоцій власних та інших людей & $4,22^{*}$ & 10,87 \\
\hline Управління власними та чужими емоціями & 7,05 & \\
\hline
\end{tabular}

Примітка: *- відмінності достовірні на рівні $\mathrm{p} \leq 0,05 ; * *$ - відмінності достовірні на рівні $\mathrm{p} \leq 0,01$

показало, що в обох групах домінуючим $є$ проблемно-орієнтовний копінг (45 \% у молодих фахівців і 52 \% у досвідчених). У разі виникнення стресової ситуації в процесі реалізації професійних обов’язків, незалежно від рівня професійного досвіду, фахівці застосовують копінг-стратегію, спрямовану на раціональний аналіз проблеми, пов'язаний із створенням і виконанням плану у складній ситуації. Копінг-поведінка в цьому разі виявлятиметься в таких формах, як самостійний аналіз ситуації, звернення по допомогу до інших, пошук додаткової інформації, що сприяє швидкому та продуктивному вирішенню проблеми.

Дещо нижчі показники досліджувані демонструють за шкалою «Емоційно-орієнтований копінг». Цей тип поведінки описує такі емоційні реакції фахівців як самозвинувачення, надмірна емоційність, агресивність, роздратованість, зацикленість на собі і заглиблення у світ фантазій. Значно менше працівники компанії (особливо досвідчені) демонструють стратегію, яка спрямовані на уникнення стресової ситуації, відволікання на інші ситуації або уникнення соціальних контактів, що призводить до тимчасового зменшення сили стресу. За субшкалами «Відволікання» та «Соціальне відволікання» досліджувані обох груп показали найнижчі результати (відповідно 26 та 14 \%). Найбільш значущі, статистично підтверджені відмінності двох груп виявлено за шкалами Уникнення $(\mathrm{p} \leq 0,05)$ та Соціальне відволікання $(\mathrm{p} \leq 0,05)$ (табл. 2). Отже, молоді фахівці частіше використовують їх для виходу із стресової ситуаціі, для накопичення чи залучення ресурсу, для усвідомлення та адекватної оцінки ситуації, для моделювання оптимальних дій у даній ситуації.

За допомогою розрахунків коефіцієнта рангової кореляції Спірмена ми визначили зв'язки отриманих показників. Кореляційний аналіз показників ЕI між собою показав, що у досвідчених фахівців вони більш тісно пов'язані між собою (7 достовірно значущих зв'язків у досвідчених фахівців проти 3 зв'язків у молодих фахівців). У вибірці досвідчених фахівців отримано значущі зв'язки між показниками «Емоційно-орієнтовний копінг» та «Розуміння емоцій власних та інших людей» $(\mathrm{r}=0,24$ за $\mathrm{p}<0,05)$, «Розуміння власних емоцій» $(\mathrm{r}=0,25$ за $\mathrm{p}<0,05)$, «Внутрішньо особистісний емоційний інтелект» $(\mathrm{r}=0,30$ за $\mathrm{p}<0,05)$. Крім того, корелюють між собою копінг-стратегія «Проблемно-орієнтовний копінг» та «Розуміння емоцій інших» $(\mathrm{r}=0,25$ за $\mathrm{p}<0,05)$, «Міжособистісний емоційний інтелект» $(\mathrm{r}=0,25$ за $\mathrm{p}<0,05)$. У виборці молодих фахівців виявлено тільки 2 значущих зв' язки. Шкала емоційно-фокусованих копінг-стратегій «Емоційно-орієнтовний копінг» прямо корелює 3 показником ЕІ «Розуміння емоцій інших» $(\mathrm{r}=0,42$ за $\mathrm{p} \leq 0,05)$ та «Розуміння власних емоцій» $(\mathrm{R}=0,42$ за $\mathrm{p} \leq 0,05)$. Отже, 3 набуттям професійного досвіду відбувається не тільки розвиток вміння розуміти і аналізувати емоції, але i уміння використовувати ці особистісні ресурси для розв'язання проблемних, стресових ситуацій.

Вищевикладене дає змогу зробити попередній висновок про вплив професійного досвіду працівників компанії на розвиток EI, що дозволяє їм усвідомлювати їх реакції на стресори та постстресову поведінку, здійснювати адаптивну підготовку до швидко змінюваних професійних умов, зменшувати емоційні затрати у стресових ситуаціях, втому тощо. Вочевидь, більш інтенсивне спілкування 3 різними категоріями клієнтів та співробітників в межах командних проектів призводить до розвитку даних здібностей і викликає необхідність використовувати емоційну сферу в рішенні проблем з клієнтами компанії та колегами і краще розуміти їх емоції.

Висновки. Професігенез є складною взаємодією особистісного, професійного та фахового 
Таблиця 2

Середні значення типів копінг-поведінки фахівців за методикою «Діагностика копінг-поведінки в стресових ситуаціях»

\begin{tabular}{|l|c|c|}
\hline \multirow{2}{*}{\multicolumn{1}{|c|}{ Вид копінгу }} & \multicolumn{2}{c|}{ Середні значення } \\
\cline { 2 - 3 } & $\begin{array}{c}\text { Молоді фахівці } \\
(\mathbf{N = 2 1 )}\end{array}$ & $\begin{array}{c}\text { Досвідчені фахівці } \\
\mathbf{( N = 2 1 )}\end{array}$ \\
\hline Проблемно-орієнтовний & 56,02 & 72,64 \\
\hline Емоційно-орієнтовний & 48,21 & 34,43 \\
\hline Уникнення & $41,08^{*}$ & $19,12^{*}$ \\
\hline Відволікання & 29,82 & 34,53 \\
\hline Соціальне відволікання & $36,75^{*}$ & $18,34^{*}$ \\
\hline
\end{tabular}

Примітка: * - відмінності достовірні на рівні $\mathrm{p} \leq 0,05$

розвитку. У процесі професійного розвитку відбувається становлення особистісних якостей і здібностей, професійних знань та умінь. Ці особистісні зміни фахівців, які відбуваються в процесі опанування і здійснення професійної діяльності, зумовлюються характером цієї діяльності, тому представники сучасних соціономічних професій суттєво відрізняються в цьому плані. Враховуючи стресогенний характер їх діяльності, умовою їх участі у опитуванні був достатній рівень їх задоволення працею, тому що тільки відповідна особистісним прагненням і мотивам людини професійна діяльність $є$ умовою особистісної гармонії, суб' єктивного благополуччя, загальної задоволеності життям.

Емпіричне дослідження показало наявність значущих відмінностей емоційного інтелекту та копінг-стратегій молодих і досвідчених працівників відділу контенту, маркетингу та акаунт-відділу як із погляду рівня розвитку цих показників, так і 3 погляду структурних зв'язків між їхніми компонентами. Розуміння власних емоцій виявилося найбільш сенситивним компонентом розвитку EI. У досвідчених фахівців зі стажем роботи 5-10 років більш розвинена здатність до розуміння та розрізнення емоцій як власних, так і оточуючих людей. У стресових ситуаціях характерним для них є проблемно-орієнтовний та емоційно-орієн- тований копінг, натомість молоді фахівці, поряд 3 цими стратегіями, також схильні до використання таких копінг-стратегій як уникнення та соціальне відволікання. В них є проблеми із здатністю до розрізнення емоцій оточуючих людей, 3 усвідомленням причин їх виникнення, з вмінням вербалізувати емоції, які вони відчувають.

Результати показали, що ЕI та копінг-стратегії $€$ тими внутрішніми ресурсами і здатностями, які, 3 одного боку, забезпечують реалізацію професійних можливостей, з іншого, зворотний вплив професіогенезу на їх становлення. Тому є сенс говорити про те, що розвиток особистісних характеристик фахівців сучасних соціономічних професій $є$ результуючим ефектом та психологічним ресурсом успішного професійного розвитку.

Проведене емпіричне дослідження визначило, 3 одного боку, подальші перспективи вивчення емоційного інтелекту як чинника адаптивної поведінки фахівців різного віку у стресових ситуаціях, з іншого, перспективи вивчення задоволення фахівців працею та суб' єктивного благополуччя як предикторів та опосередковуючих чинників успішного професійного розвитку. Перспективи подальших досліджень ми вбачаємо також у визначенні впливу професійного досвіду на особистісну та професійну успішність фахівців, зокрема, на їх суб'єктивне благополуччя.

\section{ЛІТЕРАТУРА}

1. Андреева И.Н. Эмоциональный интеллект: исследование феномена. Вопросы психологии, 2016. № 3. C. 78-86.

2. Белоконь О.В. Взаимосвязь эмоционального и социального интеллекта с лидерством : автореф. дис. ... канд. психол. наук : 19.00.01. Москва, 2008. 22 с.

3. Бодров В.А. Психология профессиональной деятельности. Теоретические и прикладные проблемы. М.: Институт психологии РАН, 2006. 623 с.

4. Бреус Ю. Эмоциональный интеллект как личностный ресурс профессионального становления представителей социономических профессий. Society, integration, education. Proceedings of the International Scientifical Conference. Rezekne. 2014. P. 65-74.

5. Вавилов В.А. Психологическая проблематика субъекта в теории профессиогенеза. Индивидуальный и групповой субъекты в изменяющемся мире: материалы межд. научно-практической конференции (Москва, 1999 г.). 1999. С. 29-31. 
6. Гордієнко В.І., Копець Л.В. Основні проблеми дослідження професіогенезу особистості в сучасній психології. Наукові записки Національного університету «Києво-Могилянська академія»: Соціол. науки. Т. 20. 2002. С. 59-64.

7. Гоулман, Д. Эмоциональный интеллект; пер. с англ. А.П. Исаевой. М.: АСТ МОСКВА ; Владимир : ВКТ, 2009. 478 с.

8. Гулий Ю.І., Научитель О.Д., Полтавська А.І. Емоційний інтелект як чинник успішної професійної діяльності працівників пожежно-рятувальних підрозділів. Вісник Харківського національного університету. Серія «Психологія», № 1009, 2012. С. 189-192.

9. Дрыгина А.С. К вопросу о взаимосвязи эмоционального интеллекта и копинг-поведения. Северо-Кавказский психологический вестник, vol. 16, no. 2, 2018, pp. 5-12.

10. Ермолаева Е.П. Преобразующие и идентификационные аспекты профессиогенеза. Психологический журнал. 1998. №4. С. 80-87.

11. Ерохина Е.В. Стратегии преодолевающего поведения и социальной адаптации при различных профилях эмоционального интеллекта: дис. ... канд. психол. наук : 19.00.05. Краснодар., 2011. 211 с.

12. Зеер Э.Ф. Психология профессионального развития: Учебн. пособие. 2-е изд. М.: Издательский центр «Академия», 2007. 240 с.

13. Иванова Т.Ю., Рассказова Е.И., Осин Е.Н. Структура и диагностика удовлетворенности трудом: разработка и апробация методики. Организаџионная психология, 2012, 2 (3), С. 2-15.

14. Ковалёва О.А. Связь эмоционального интеллекта со стратегиями совладающего поведения предпринимателей и топ-менеджеров. Вестник Костромского государственного университета. Серия: Педагогика. Психология. Социокинетика, vol. 21, no. 4, 2015, pp. 125-129.

15. Кокун О.М. Психологія професійного становлення сучасного фахівця: Монографія. К.: ДП «Інформ.-аналіт. агентство», 2012. 200 с.

16. Кутеева В.П., Юлина Г.Н., Рабаданова Р.С. Эмоциональный интеллект как основа успешности в профессиональной деятельности Отечественная и зарубежная педагогика. 2012. № 3(6). С. 59-65.

17. Люсин Д.В. Современные представления об эмоциональном интеллекте. Социальный интеллект: Теория, измерение, исследования / [под ред. Д. В. Люсина, Д.В. Ушакова]. М.: Ин-тут психологии PAH, 2004. C. 29-36.

18. Люсин Д.В. Опросник на эмоциональный интеллект ЭмИн: новые психометрические данные. Социальный и эмоциональный интеллект: от процессов к измерениям / отв. ред. Д. В. Люсин, Д. Ушаков. М.: Институт психологии РАН, 2009. С. 264-278.

19. Носенко Е.Л. Емоційний інтелект як соціально значуща інтегральна властивість. Психологія $і$ суспільство. 2004. № 4. С. 95-109.

20. Панкова Т.А. Эмоциональный интеллект как фактор социально-психологической адаптации молодых специалистов : дис. ... канд. психол. наук : 19.00.05. М., 2011. 208 с.

21. Пашко Т.А. Емоційний інтелект як складова професійної компетентності керівника. Науковий часопис Національного педагогічного університету імені М.П. Драгоманова. Серія 12 : Психологічні науки. 2008. № 21 (45). С. 161-167.

22. Петровская А.С. Эмоциональный интеллект как детерминанта результативных параметров и процессуальных характеристик управленческой деятельности: дисс. канд. психолог. наук: 19.00.03. Ярославль, 2007.

23. Ракітянська Л. Становлення та розвиток поняття «емоційний інтелект»: історико-філософський аналіз. Неперервна професійна освіта: теорія і практика (Серія: Педагогічні науки). 2018. № 3-4 (56-57). C. 36-42.

24. Темрук О., Колісник Л. Проблема емоційного інтелекту на сучасному етапі розвитку психологічної думки. Гуманітарний вісник Державного вищого навчального закладу Переяслав-Хмельницький державний педагогічний університет імені Григорія Сковороди. Педагогіка. Психологія. Філосорія. 2014. Вип.33. С. 207-223

25. Ткаченко А.В. Категоріальний статус поняття «професійний розвиток особистості». Витоки педагогічної майстерності. 2011. Вип. 8 (2). С. 263-269

26. Федяева И.Ю. Взаимосвязь профессиональной мотивации и удовлетворенности трудом работников предприятия. Вестник ВятГУ. 2018. №4. URL: https://cyberleninka.ru/article/n/vzaimosvyaz-professionalnoymotivatsii-i-udovletvorennosti-trudom-rabotnikov-predpriyatiya (дата обращения: 08.01.2021).

27. Четверик-Бурчак А.Г. Механізми впливу емоційного інтелекту на успішність життєдіяльності особистості. Дніпропетровськ, 2015. 187 с.

28. Хоржевська I.М. Професіоналізм та професійний розвиток особистості. Наука і освіта. 2016. № $11.55-60$. 
29. Ягупов В.В. Професійний розвиток особистості фахівця: поняття, зміст та особливості. Наукові записки НаУКМА. Педагогічні, психологічні науки та соиіальна робота. 2015. Т. 175. С. 22-28.

30. Alon, I., \& Higgins, J.M. Global leadership success through emotional and cultural intelligences. Business Horizons, 2005. 48, 501-512.

31. Barling, J., Slater, F., \& Kelloway, E.K. Transformational leadership and emotional intelligence: An exploratory study. Leadership and Organization Development Journal, 2000. 21(3), 157-161.

32. Bar-On R. Emotional Intelligence Inventory (EQ-I): Technical Manual. Toronto: Multi-Health System, 1997. $134 \mathrm{~s}$.

33. Gabel, R.S., Dolan, S.L., \& Cerdin, J.L. Emotional intelligence as predictor of cultural adjustment for success in global assignments. Career Development International, 2005. 10(5), 375-395.

34. Gardner L., \& Stough, C. Examining the relationship between leadership and emotional intelligence in senior level managers. Leadership \& Organization Development Journal, 23(2), 68-78.

35. Hoffmann B. The relationship between emotional intelligence and leadership among middle managers in namibia. university of Namibia. Thesis for the degree master of arts (industrial psychology). 2010. 173 http://repository.unam.edu.na/bitstream/handle/11070/539/hoffmann2010.pdf?sequence=1

36. Mayer J.D., Salovey P., Caruso D. Models of emotional intelligence. Handbook of Human Intelligence / R. J. Sternberg (Ed.). Cambrige, UK: Cambrige University Press, 2000. P. 396-420.

37. Mayer J.D., Salovey P. The Intelligence of emotional intelligence. Intelligence. 1993. V.17. № 4. P. 433-442.

38. Petrides K., Furnham A. Trait emotional intelligence: behavioural validation in two studies of emotion recognition and reactivity to mood induction. 2002. https://doi.org/10.1002/per.466 URL: https://onlinelibrary.wiley.com/doi/10.1002/per.466 (дата звернення 21.01.2020).

39. Kerr R., Garvin J., Heaton N. and Boyle E. Emotional intelligence and leadership effectiveness, Leadership \& Organization Development Journal, 2006. Vol. 27 No. 4, pp. 265-279. https://doi.org/10.1108/01437730610666028

40. Legier, John T., Jr. Assessing leadership effectiveness: The relationship between emotional intelligence and leadership behaviors on group and organizational performance. Southern Illinois University at Carbondale, ProQuest Dissertations Publishing, 2011. 56-67.

41. Lugo M.V. Cultural and emotional intelligences in the development of global transformational leadership skills. Unpublished doctoral dissertation, Bridgewater, 2007. 149-187 https://citeseerx.ist.psu.edu/ viewdoc/download?doi=10.1.1.227.1815\&rep=rep1\&type $=$ pdf

42. Salovey P., Mayer J.D., Goldman S.L., Turvey C., \& Palfai T.P. (1995). Emotional attention, clarity, and repair: Exploring emotional intelligence using the Trait Meta-Mood Scale. In J. W. Pennebaker (Ed.), Emotion, disclosure, \& health (p. 125-154). American Psychological Association. https://doi.org/10.1037/10182-006

\section{REFERENCES}

1. Andreeva I.N. (2011) Jemocional'nyj intellekt: issledovanie fenomena. Voprosy psihologii,. № 3. (pp 78-86). Novopolock: "PSU" [in Russian]

2. Belokon' O.V. (2008) Vzaimosvjaz' jemocional'nogo i social'nogo intellekta s liderstvom [dissertation abstract.] (p 22) Moscow: Institute of Psychology named after LS Vigotsky, Russian State University for the Humanities [in Russian]

3. Bodrov V.A. (2006) Psihologija professional'noj dejatel'nosti. Teoreticheskie i prikladnye problemy. (p 623) Moscow: Institut psihologii RAN. [in Russian]

4. Breus Ju. (2014) Jemocional'nyj intellekt kak lichnostnyj resurs professional'nogo stanovlenija predstavitelej socionomicheskih professij. [Proceedings of the International Scientific Conference.] (pp 65-74) Kyiv: Borys Hrinchenko University of Kyiv [in Russian]

5. Vavilov V.A. (1999) Psihologicheskaja problematika subekta v teorii professiogeneza. Individual'nyj $i$ gruppovoj subekty v izmenjajushhemsja mire [materials of the international scientific and practical conference] (pp 29-31) Moscow: Institute of Psychology of the Russian Academy of Sciences [in Russian]

6. Gordiyenko V.I., Kopecz` L.V. (2002) Osnovni problemy` doslidzhennya profesiogenezu osoby `stosti v suchasnij psy xologiyi. [proceedings] (pp 59-64) Kyiv: National University of Kyiv-Mohyla Academy [in Ukrainian].

7. Goulman, D. (2009) Jemocional'nyj intellekt; per. s angl. A.P. Isaevoj. (p 478) Moscow: ACT MOSKVA; [in Russian].

8. Guly`j Yu.I., Nauchy`tel` O.D., Poltavs`ka A.I. (2012) Emocijny`j intelekt yak chy`nny`k uspishnoyi profesijnoyi diyal nosti pracivny kiv pozhezhno-ryatuval ny`x pidrozdiliv. (pp 189-192) Kharkiv: Visnyk Kharkivs 'kogo nacional nogo universy`tetu . Seriya "Psy'xologiya", \#1009, [in Ukrainian]. 
9. Drygina A.S. (2018) K voprosu o vzaimosvjazi jemocional'nogo intellekta i koping-povedenija. (pp. 5-12) Rostov-on-Don: North Caucasian psychological bulletin, vol. 16, no. 2, [in Russian].

10. Ermolaeva E.P. (1998) Preobrazujushhie i identifikacionnye aspekty professiogeneza [psychological journal] (pp 80-87) Moscow: Federal State Budgetary Institution "Russian Academy of Sciences" [in Russian].

11. Erohina, E.V. (2011) Strategii preodolevajushhego povedenija i social'noj adaptacii pri razlichnyh profiljah jemocional'nogo intellekta [dissertation of the candidate of psychological sciences] (p 211) Krasnodar: Kuban State University [in Russian].

12. Zeer Je.F. (2007) Psihologija professional'nogo razvitija [schoolbook] (p 240) Moscow: «Akademija» [in Russian].

13. Ivanova, T.Ju., Rasskazova, E.I., Osin, E.N. (2012) Struktura i diagnostika udovletvorennosti trudom: razrabotka i aprobacija metodiki. [organizational psychology] (pp 2-15) Moscow: Lomonosov Moscow State University [in Russian].

14. Kovaljova O.A. (2015) Svjaz' jemocional'nogo intellekta so strategijami sovladajushhego povedenija predprinimatelej i top-menedzherov. [Research Article] (pp. 125-129). Kostroma: Vestnik Kostromskogo gosudarstvennogo universiteta. Serija: Pedagogika. Psihologija. Sociokinetika, vol. 21, no. 4 [in Russian].

15. Kokun O.M. (2012) Psy xologiya profesijnogo stanovlennya suchasnogo faxivcya: Monografiya. (p 200) Kyiv: DP "Inform.-analit. agenstvo" [in Ukrainian].

16. Kuteeva V.P., Julina G.N., Rabadanova R.S. (2012) Emocionalnij intellekt kak osnova uspeshnosti v professional'noj deyatelnosti [domestic and foreign pedagogy] (pp 59-65). Yekaterinburg: Ural Federal University named after the first President of Russia B.N. Yeltsin [in Russian].

17. Ljusin D.V. (2004) Sovremennye predstavlenija ob jemocional'nom intellekte. Social'nyj intellekt: Teorija, izmerenie, issledovanija (pp 29-36) Moscow: In-tut psihologii RAN. [in Russian].

18. Ljusin D.V. (2009) Oprosnik na jemocional'nyj intellekt JemIn: novye psihometricheskie dannye. Social'nyj i jemocional'nyj intellekt: ot processov k izmerenijam (pp 264-278) Moscow: Institut psihologii RAN [in Russian].

19. Nosenko E.L. (2004) Emocijny ’’ intelekt yak social ’no znachush ha integral 'na vlasty vist'. Psy ‘xologiya i suspil stvo. (pp 95-109). Kyiv: PSYKHOLOHIYA I SUSPIL'STVO [in Ukrainian].

20. Pankova T.A. (2011) Jemocional'nyj intellekt kak faktor social'no-psihologicheskoj adaptacii molodyh specialistov [dissertation of the candidate of psychological sciences] (p 208) Moscow. [in Russian].

21. Pashko T.A. (2008) Emocijny ` intelekt yak skladova profesijnoyi kompetentnosti kerivny $k a$. [scientific journal] (pp 161-167) Kyiv: Dragomanov National Pedagogical University [in Ukrainian].

22. Petrovskaja A.S. (2007) Jemocional'nyj intellekt kak determinanta rezul'tativnyh parametrov i processual'nyh harakteristik upravlencheskoj dejatel'nosti [dissertation of the candidate of psychological sciences] Yaroslavl': bibliography [in Russian].

23. Rakityans`ka L. (2018) Stanovlennya ta rozvy`tok ponyattya «emocijny`j intelekt»: istory 'ko-filosofs 'ky $\mathrm{j}$ analiz. Neperervna profesijna osvita: teoriya i prakty $k a$ (pp 36-42). Kyiv: Pedagogichni nauky [in Ukrainian].

24. Temruk O., Kolisny'k L. (2014) Problema emocijnogo intelektu na suchasnomu etapi rozvy 'tku psy ’xologichnoyi dumky`. (pp 207-223). Pereyaslav: Humanitarian Bulletin of the State Higher Educational Institution "Pereyaslav-Khmelnytsky State Pedagogical University named after G. Skovoroda" [in Ukrainian].

25. Tkachenko A.V. (2011) Kategorial 'ny`j status ponyattya "profesijny`j rozvy`tok osoby stosti». [The origins of pedagogical skills] (pp 263-269). Kyiv: Vernadsky National Library of Ukraine [in Ukrainian].

26. Fedjaeva I.Ju. (2018) Vzaimosvjaz' professional'noj motivacii i udovletvorennosti trudom rabotnikov predprijatija. Retrieved from https://cyberleninka.ru/article/n/vzaimosvyaz-professionalnoy-motivatsii-i-udovletvorennosti-trudom-rabotnikov-predpriyatiya (08.01.2021). [in Russian].

27. Chetvery`k-Burchak A.G. (2015) Mexanizmy'vply'vu emocijnogo intelektu na uspishnist 'zhy 'ttyediyal 'nosti osoby `stosti. ( $\mathrm{p}$ 187) Dnipropetrovs`k: KD Ushinsky South Ukrainian National Pedagogical University [in Ukrainian].

28. Khorzhevska I.M. (2016) Profesionalizm ta profesijny jo rozvytok osobystosti. Nauka i osvita.(pp 55-60) Mykolaiv: Petro Mohyla Black Sea State University. [in Ukrainian].

29. Yagupov V.V. (2015) Profesijny ’ rozvy`tok osoby 'stosti faxivcya: ponyattya, zmist ta osobly 'vosti. [proceedings] (pp 22-28) Kyiv: NaUKMA [in Ukrainian].

30. Alon I., \& Higgins J.M. (2005) Global leadership success through emotional and cultural intelligences. (pp 48, 501-512) Business Horizons.

31. Barling J., Slater F., \& Kelloway E.K. (2000) Transformational leadership and emotional intelligence: An exploratory study. (pp 157-161) Leadership and Organization Development Journal. 
32. Bar-On R. (1997) Emotional Intelligence Inventory (EQ-I): Technical Manual. (p 134) Toronto: MultiHealth System.

33. Gabel R.S., Dolan S.L., \& Cerdin J.L. (2005) Emotional intelligence as predictor of cultural adjustment for success in global assignments. Career Development International,. 10(5).

34. Gardner L., \& Stough C. (2002) Examining the relationship between leadership and emotional intelligence in senior level managers. Leadership \& Organization Development Journal, 23(2), 68-78.

35. Hoffmann B. (2010) The relationship between emotional intelligence and leadership among middle managers in namibia. university of Namibia. Thesis for the degree master of arts (industrial psychology). http://repository.unam.edu.na/bitstream/handle/11070/539/hoffmann2010.pdf?sequence=1

36. Mayer J.D., Salovey R., Caruso D. Models of emotional intelligence. Handbook of Human Intelligence / R. J. Sternberg (Ed.). (pp 396-420) Cambrige, UK: Cambrige University Press.

37. Mayer J.D., Salovey P. (1993) The Intelligence of emotional intelligence. Intelligence. (pp 433-442). USA. https://doi.org/10.1016/0160-2896(93)90010-3

38. Petrides K., Furnham A. (2002) Trait emotional intelligence: behavioural validation in two studies of emotion recognition and reactivity to mood induction.. https://doi.org/10.1002/per.466.

39. Kerr R., Garvin J., Heaton N. and Boyle E. (2006) Emotional intelligence and leadership effectiveness, Leadership \& Organization Development Journal,. Vol. 27 No. 4, (pp. 265-279). https://doi.org/10.1108/01437730610666028

40. Legier, John T., Jr. Assessing leadership effectiveness: The relationship between emotional intelligence and leadership behaviors on group and organizational performance. (pp 56-67) USA: Southern Illinois University at Carbondale, ProQuest Dissertations Publishing.

41. Lugo M.V. (2007) Cultural and emotional intelligences in the development of global transformational leadership skills. [Unpublished doctoral dissertation], (pp 149-187) United Kingdom: Bridgewater. https://citeseerx.ist.psu.edu/viewdoc/download?doi=10.1.1.227.1815\&rep=rep1

42. Salovey P., Mayer J.D., Goldman S.L., Turvey C., \& Palfai T.P. (1995). Emotional attention, clarity, and repair: Exploring emotional intelligence using the Trait Meta-Mood Scale. In J. W. Pennebaker (Ed.), Emotion, disclosure, \& health (p. 125-154). American Psychological Association. https://doi.org/10.1037/10182-006. 